A N N A LES

UNIVERSITATIS MARIAE CURIE-SKŁODOWSKA

L U B L I N - P O L O N I A

VOL. LXVII, 1

SECTIO B

2012

Maria Curie-Skłodowska University in Lublin, Faculty of Earth Sciences and Spatial Management

Department of Geoecology and Paleogeography

MARTA KUSZNERCZUK

\title{
Contemporary hazards of the Bug lateral erosion in the Polish-Belarus border area
}

Współczesne zagrożenia erozyjne Bugu na pograniczu polsko-białoruskim

\begin{abstract}
In this paper the changes of river and border position caused by lateral erosion between Poland and Belarus are considered. The research area was the Middle Bug River valley near Janów Podlaski. The investigated section of this river (35-km in length) is characterized by different channel pattern in accordance with the changes of width of the valley. Generally meandering or winding river is in metamorphosis to braiding in a very narrow part of the valley. Cartographic materials used (archival maps, aerial photographies and ortophotomaps) were allowed to determine the changes of the river position and its morphometric parameters in the chosen periods since 1839. The trend of erosional strength and pattern depends on the type of channel pattern and resistance of river bank. The flood hazard in the bottom valley is also considered in this paper.
\end{abstract}

Key words: lateral erosion, cartographic methods, channel pattern, Bug River valley

\section{INTRODUCTION}

The Bug River, the biggest left-bank tributary of the Narev, along $171 \mathrm{~km}$ of its length is a border with Belarus. In this aspect the recognition of erosional hazards is very important. The situation where the lateral erosion causes cutting the territories of Poland or Belarus has occurred. The Bug River is almost unregulated. The hydrotechnical constructions aimed to limit bank erosion there usually do not exist.

The research into erosion of the Bug River was conducted over the $35-\mathrm{km}$ long section (22.0-22.5 according to mileage) of the river near Janów Podlaski, between Zaczopki and Gnojno (up to changes on the land border). According to 
physical division of Poland (Kondracki 2000) this area is located in the macroregion South Podlasie Lowland, mesoregion of Podlasie Bug River Gap. In the research area the Bug River valley is distinctly diverse from the morphological point of view. There are three sections of the river valley with different channel pattern: 1) the section of a wide valley between Zaczopki and Wygoda, with meandering channel; 2) the transitional section of a valley between Wygoda and Buczyce Stare, with straight channel; 3) the section of a narrow valley between Buczyce Stare and Gnojno, with winding channel. The changeable width of the Bug river valley is shaped mainly by the features of glacial relief surrounding this valley.

In the investigated area it is possible to recognize the influence of natural factors on the changes of channel position and its morphological features because of slight human impact in the environment of the Bug River valley. A formation of suitable channel pattern is achieved there, depending on the course of the fluvial processes, including erosional processes. The problem of different factors which influence channel developing is much more complicated. Despite the natural impact, widely understood economic human activity in the drainage basin also plays a key role. Deforestation and the progressing intensification of farming cause increasing runoff surface and its concentration (Klimek 1987). This leads to increased delivery of sediments to the river channel (Lajczak 1988). Furthermore, the retention of the drainage basin has a decreasing tendency. This contributes to increasing magnitude and/or frequency of floods (Klimek 1987).

The cartometric measures of bends and photointerpretation based on change of channel position had a dominating role among the applied research methods. In this case archival maps, aerial photographies and orthophotomaps (some parts of methodology after Trafas 1975) were used. These measurements and channel position analysis were conducted from 1939 (used visually), and then in the following periods: 1911-1915, 1939-1944, 1971-1981, 2003 (detailed study). The changes observed on cartographic materials were concluded on the basis of geological recognitions of river deposits.

\section{MATERIALS AND RESEARCH METHODS}

Analysed maps in a large scale 1:100 000 and larger were used as archival materials. These maps were calibrated to one system of coordinates (the calibration based on WIG maps was chosen on account of the highest reliability and detailed information). These are the following maps: 1) Topographic Map of the Congress Kingdom of Poland from 1839, at a scale 1: 126000 (used in certain situations); 2) Karte des westlichen Russland from 1911 at a scale 1:75 000, sheets Biała and Janów (incomplete covering); 3) Karte des westlichen Russland from 1915 at a scale 1:100 000, sheets: Biała, Brest, Siemiatycze; 4) Grobblatt 
from 1930-1931 at a scale 1:100 000, sheets: Biała Podlaska, Brest on the Bug (incomplete covering); 5) Maps of the Military Geographic Institute from 19311937 at a scale 1:100 000, sheets: Biała Podlaska, Brest, Siemiatycze; 6) War and Navy Department Agencies from 1944, at a scale 1:100 000, sheets: Siemiatycze, Biała Podlaska.

The use of aerial photography and orthophotomaps aimed at reconstructing the recent changes. The collected materials included: 1) aerial photographs from 1971 at a scale 1:18 000 (incomplete covering); 2) aerial photographs from 1981 at a scale 1:25 000 (incomplete covering), Topographic Map from 1982, at a scale 1:10 000 (this map was used only to fill in the incomplete covering in aerial photography from 1981); 3) orthophotomaps from 2003, at a scale 1:5 000. All aerial photographs (the central projection from one point, sometimes a bit oblique) were calibrated to orthophotomaps as the most reliable material. Different ways of calibration on stable elements were used in the process of photography adoption. In the case of photography with a small number of stable points (e.g. crossroads, corner of buildings, cross channels of melioration system) the straight calibracy was used, $2^{\text {nd }}$ degree. This higher degree of calibration used for photography might have caused a considerable deviation from the appropriate position in places without calibration points. The stronger transformation, $3^{\text {rd }}$ degree, was used in the case of photography with many stable points. That transformation caused the photography to stretch and adapt to defined coordinates. While using the $2^{\text {nd }}$ degree transformation, the average error on the calibrated points was maximally $4-5 \mathrm{~m}$, whereas using the $3^{\text {rd }}$ transformation, the error was up to $1-2 \mathrm{~m}$.

The geometric parameter of active channel bend was measured in order to obtain the full characteristics of changed channel position. The single river bend was taken as a basic unit of measurements. From the erosional processes point of view the following geometric measure was chosen (after Leopold and Wolman 1960; Trafas 1975): the curvature radius of bend, the length of bend and the asymmetry index of bend.

Based on the possession of cartographic material the cartometric and photointerpretive final analysis was carried out in the Geographic Information System (GIS) environment using Arc Gis v. 9.3 software.

\section{FLOODS HAZARD}

The highest erosion of the Bug River is during the floods and full-channel conditions. Flood has occurred when the threshold of functioning drainage basin had been exceeded (Kostrzewski 2002). According to contemporary and historical hydrological data (Institute of Meteorology and Water Management), higher surge (floods often surge) in the spring thaw took place. During the ice cover formation the level of water in the channel could rise even $1 \mathrm{~m}$ per day (Plan ope- 
racyjny ochrony przed powodziq ..., 2003). The average discharge of flood surge is $2.5 \mathrm{~km} / \mathrm{h}$. The culmination of storm/swelling surge is often preceded by bank up of water level in channel by ice phenomenon, including ice jam. In the period 1974-2003 ice jam was formed at the $240^{\text {th }} \mathrm{km}$ of the river course near the village Wygoda and at the $232^{\text {th }} \mathrm{km}$ of the river course near the village Buczyce Stare. The hydrotechnical devices do not exist on the whole length of the research valley, excluding the $1.7 \mathrm{~km}$-long embankments surrounding the buildings of Wygoda village. The bank of the river is locally strengthened by a wicker fascine. These efforts were conducted in the 60's of the $20^{\text {th }}$ century and later according to data from the Janów Podlaski District Council. This form of bank reinforcement is well composed with landscape, and is almost unnoticeable. Only the $120 \mathrm{~m}$ long river-side band near Wygoda village made from local material (local stones and debris) is clearly visible.

The historical sources give some examples of catastrophic floods in the Bug River valley. One of them could be in 1551, when the bridge near Mielnik (a village located a few kilometers upward the river course) was damaged (Michaluk 2004). This damage might have been caused by the Bug River channel's changes of position. In the period of regular observations the highest floods happened in the following years: 1888, 1924, 1958, and 1979 (Mierkiewicz, Sasim 2003). The flood in March and April in 1979 was the highest in the fifty-year period 1951-2000 and probably it was a catastrophic disaster comparable with a flood from 1888. Gloger (1903) also points out the year 1729 as a year in which "after deep snow there was big water in the Bug River".

In the case of one hundred-year floods (probability is $1 \%$ ), the flooding area of the left-bank valley equals $45 \mathrm{~km}^{2}$ (study based on Plan operacyjny ochrony przed powodziq..., 2003 ). Eleven villages are under threat in the research part of the Bug River valley (Fig. 1). These are the places of ice jams near Wygoda, in the very narrow bend of the river. These jams may lead to hazardous floods.

\section{STUDIES ON GEOMETRIC PARAMETERS OF THE RIVER BEND IN THE ASPECT OF EROSIONAL HAZARD OF THE BUG RIVER}

The pattern of channel reflects the course of erosional processes. In order to determine the range of lateral erosion the changes of position and shape of the channel should be taken into consideration in the meandering river.

The channel of the Bug River is developed differently on the investigated area between Zaczopki and Gnojno. In the wide section of the valley the river is meandering. Regarding the size, the meanders are considerably diverse. Then with the decreasing width of the valley bottom the channel surrenders straightening. The existing curvatures of channel are the effects of forced channel swinging from one river side to the other in the narrow section of the valley. 
In the course of research the changes of the curvature radius, the length and the asymmetry index of bends were determined for the contemporary active bends. In the period 1911-2003 the straight majority of bends have radius in the range 150-450 $\mathrm{m}$ according to the conducted analysis of changes of the curvature radius of bends. For particular periods the arithmetic mean was: 1911-1915 $360 \mathrm{~m} ; 1930-1944-505 \mathrm{~m} ; 1971-1981-495 \mathrm{~m} ; 2003-468 \mathrm{~m}$. The analyzed information about bends' development is referring to the classic cycle of meander development (Kondratiew 1968). According to this cycle, it is assumed that the more developed meander, the lesser its curvature radius. The conducted analyses based on one hundred-year changes of the bends length prove the decreasing tendency in most causes. Only in the first analyzed period 1911-1915 there was a little growth of the curvature radius, which is possibly a result of the lack of precision of these historical maps. The noted increasing length of bends is also in accordance with the classic cycle of meander development mentioned before.

Taking into consideration the asymmetry index of bends, the odd numbers of bends (right bends) relative to the axis of symmetry are moving to the right. In the case of even numbers of bends (left bends), they are moving to the left. Using this index, the synchronous rotation of bends in the clockwise direction was observed (Fig. 2). These bends are generally sliding down with the course of the river. The Bug River in the section between Zaczopki and Gnojno has changed its position significantly since 1839. Near Wygoda and Bubel Stary two bends were cut in this period.

From among 21 cartometric analyzed bends three of them - number 5, 12 and 21 - are very interesting. These bends chosen for further presentation below are located in different sections of the Bug River valley.

The river bend no. 5 in almost one hundred-year period has passed two phases of development according to the model adopted from Kondratiew (1968). This bend was moved $180 \mathrm{~m}$, its circular shape was distorted. After 1944, new bends started to emerge $-5 \mathrm{a}, 5 \mathrm{~b}$. This process is connected with different local bank resistance. The lateral erosion is limited in the place where a paleochannel is filled by strong resistant organic deposits with the wood fragments. These paleochannel deposits are visible in the right river bank. The lateral erosion also limited by stone weir which is the residue of watermill (?) linked with the landed estate Łozowica (Belarus area). This weir could not be washed away despite the hazardous lateral erosion in this place. The land of Łozowica estate was located on older floodplain. The paving road and the outline of buildings document this estate. One of those paving roads was constructed along the river side. The bank is more resistant there. Probably the transition of bend 5 to the next phase, where the neck of meander is narrowing, could be even faster. The 820-m long wicker fascine was used in order to prevent very strong erosion of the left bank. This fascine was broken after 1981. The stages of bend 5 development are presented in Figure 3. 
The river bend no. 12 has changed significantly. Channel position was moved over $250 \mathrm{~m}$ after 1944. The right bank of the Bug River is eroded there. This is strictly connected with a big (700 $\mathrm{m}$ in length) consolidated island. This island is separated from the left river bank by narrow, about $20 \mathrm{~m}$-long arm of the channel. Certainly this island was developed as a result of fierce moving of the channel next to the right bank in the period 1944-1971. Then some part of the right bank was cut, probably it was made from more resistant deposits. This was confirmed by hand-made sound which was done within the island. The sand deposits lies on a thick series of silts under the surface (above $1.5 \mathrm{~m}$ ). This layer of silty deposits could indicate the roof of paleochannels. The right bank is strongly eroded as a result of changes in the main river current. Since the 70 's of the $20^{\text {th }}$ century this right bank moved back (upwards) locally about $50 \mathrm{~m}$. The narrow left arm of the channel with a small discharge is silted now. The arm which disappeared is rejuvenated only during the spring melt, when huge amount of water is pouring there. Then some parts of deposits are removed, which contributed to the deepening of this arm. This is confirmed by lithology (granulation analysis) of a small island situated in the inlet of the arm. Alternate layers of the medium-grained sands deposited by saltation during the high water level were recognized there as well as the fine-grained sands and silts deposited by suspension during the low water level in the Bug River. It is worth mentioning that this left channel arm was active for a short time. It was developed by cutting of the bend in the neck after 1839 (see Fig. 2). Because of strong erosion of the right river bank (mentioned before) after 1944, two subsequent bends were developed - 12a and 12b. In the case of the bend no. 12a the changes of its shape and its position were connected with the strengthening of this bank by $120 \mathrm{~m}$ in length wicker fascine in the 60 's of the $20^{\text {th }}$ century. In the case of the bend no. $12 \mathrm{~b}$, its curvature radius has a decreasing tendency. The hazardous lateral erosion was reported on the left river side since 1971. In the late 90's the stone band of the bank was used there due to prevention of the Polish territory. As a result, the lateral erosion was limited, but the deep erosion increased. The deepest channel with the strongest whirlpool in the whole research section of the Bug River valley is located there. The main lateral erosion moved just after the prevention of erosion band. This can be observed recently (since about 2004). Wide niche is developing $40 \mathrm{~m}$ along the river bank. The situation is presented in Figure 4. 


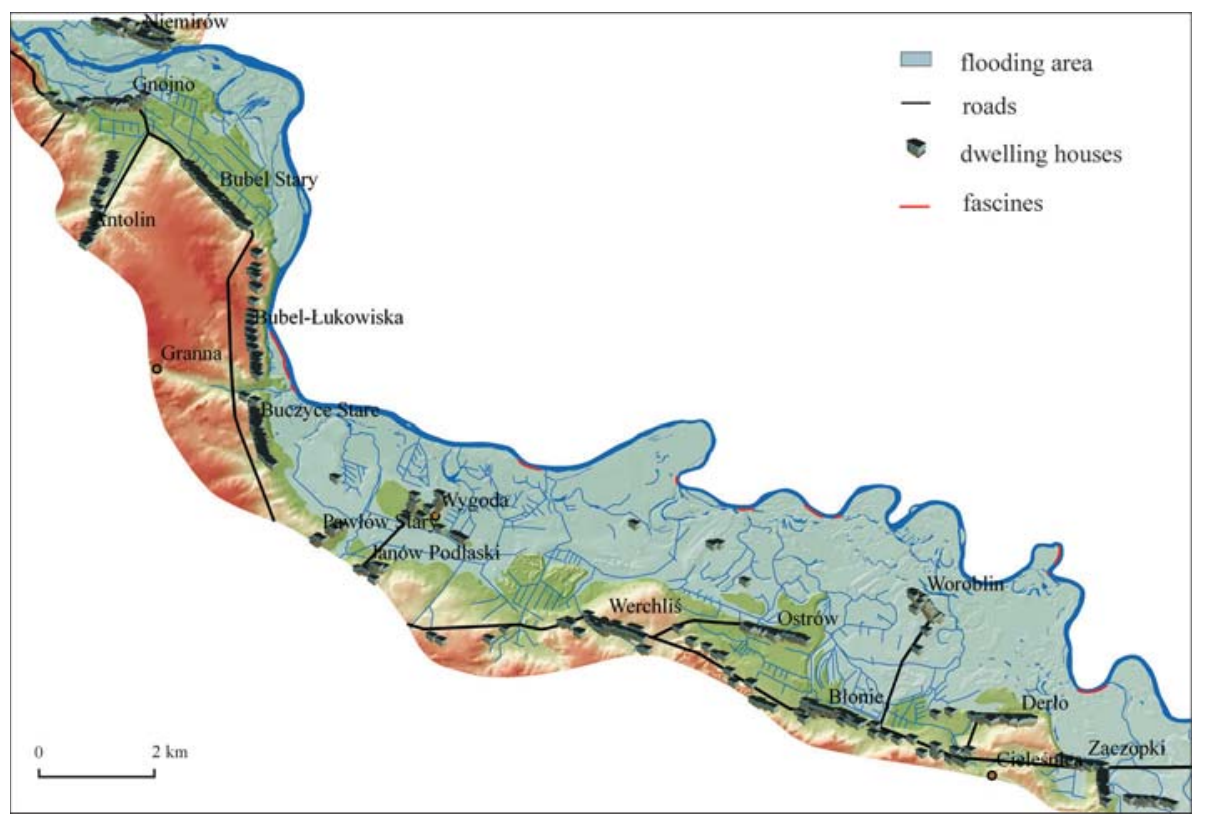

Fig. 1. The model of one hundred-year floods in the left-bank Bug River valley (based on Plan operacyjny ochrony przed powodziq..., 2003, supplemented)

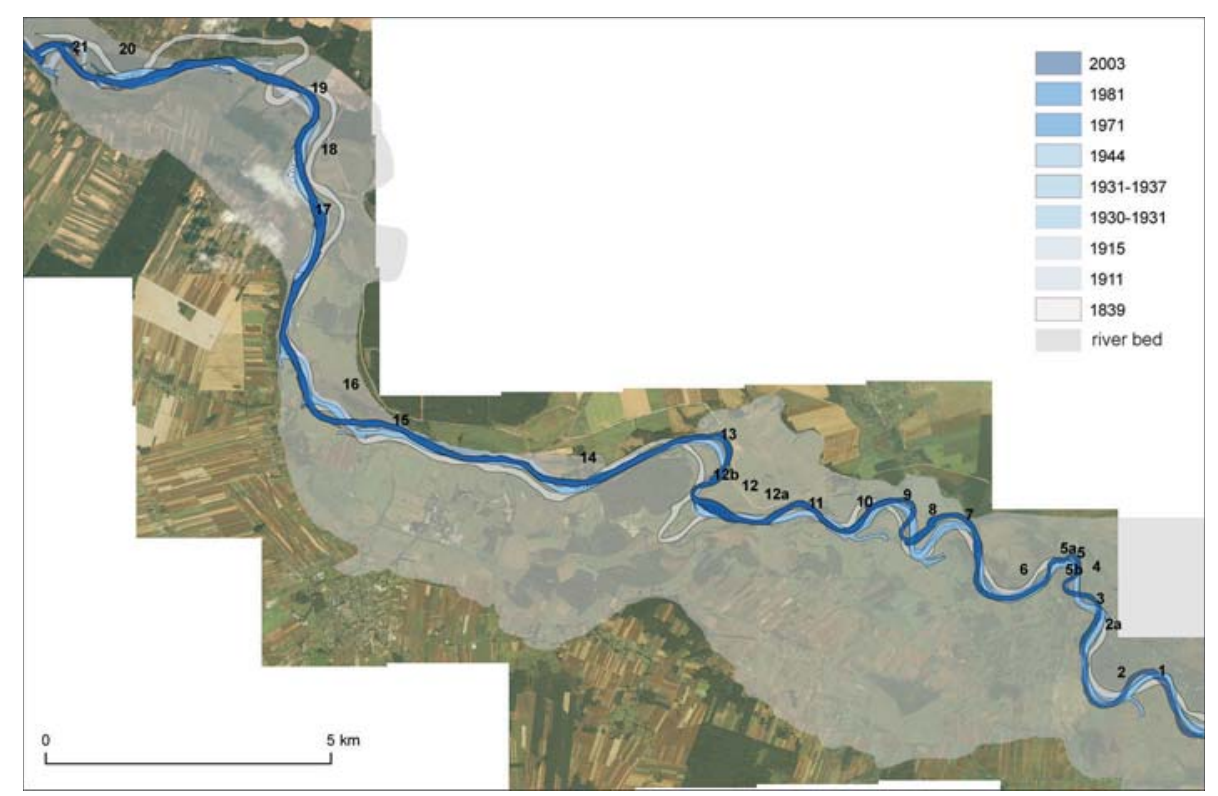

Fig. 2. The changes of Bug River channel position in the period 1839-2003 


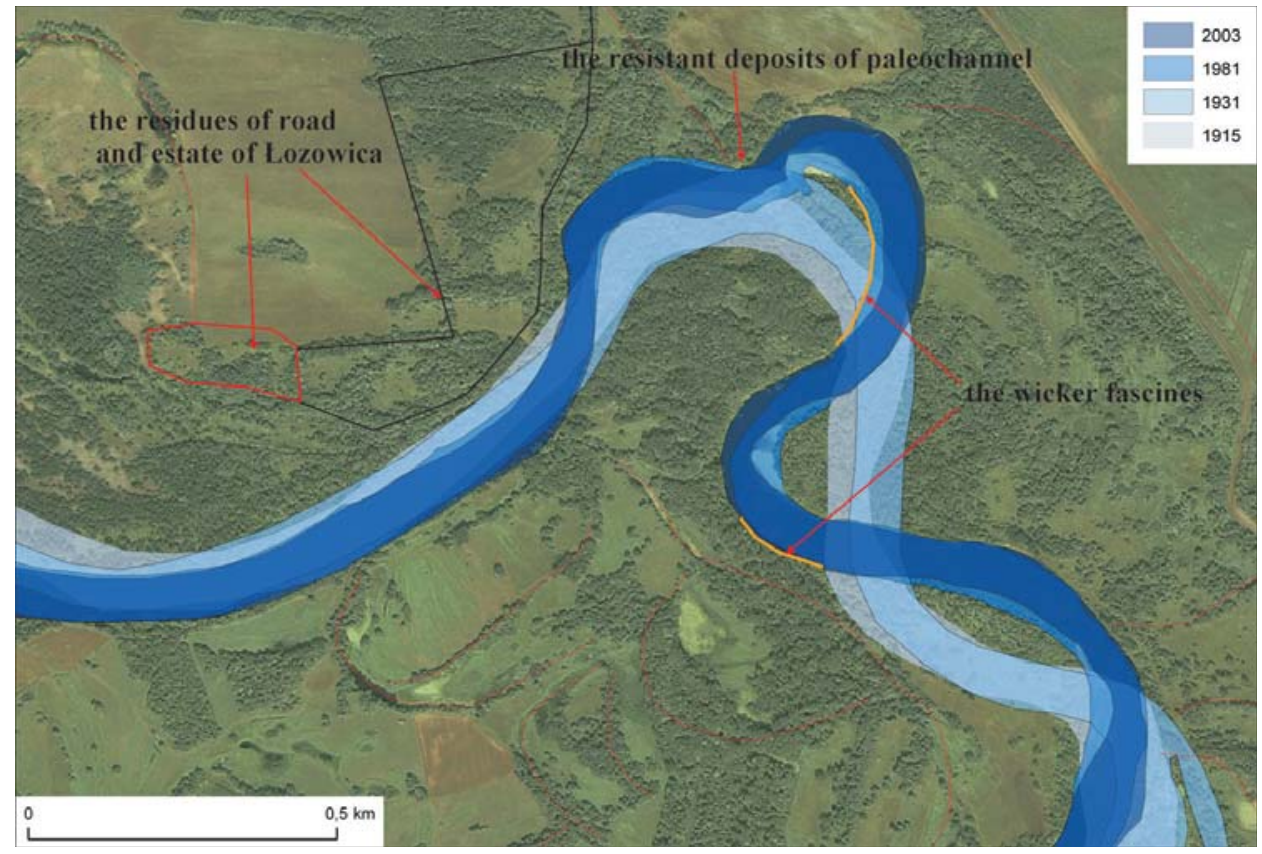

Fig. 3. The stages of bend no. 5 development

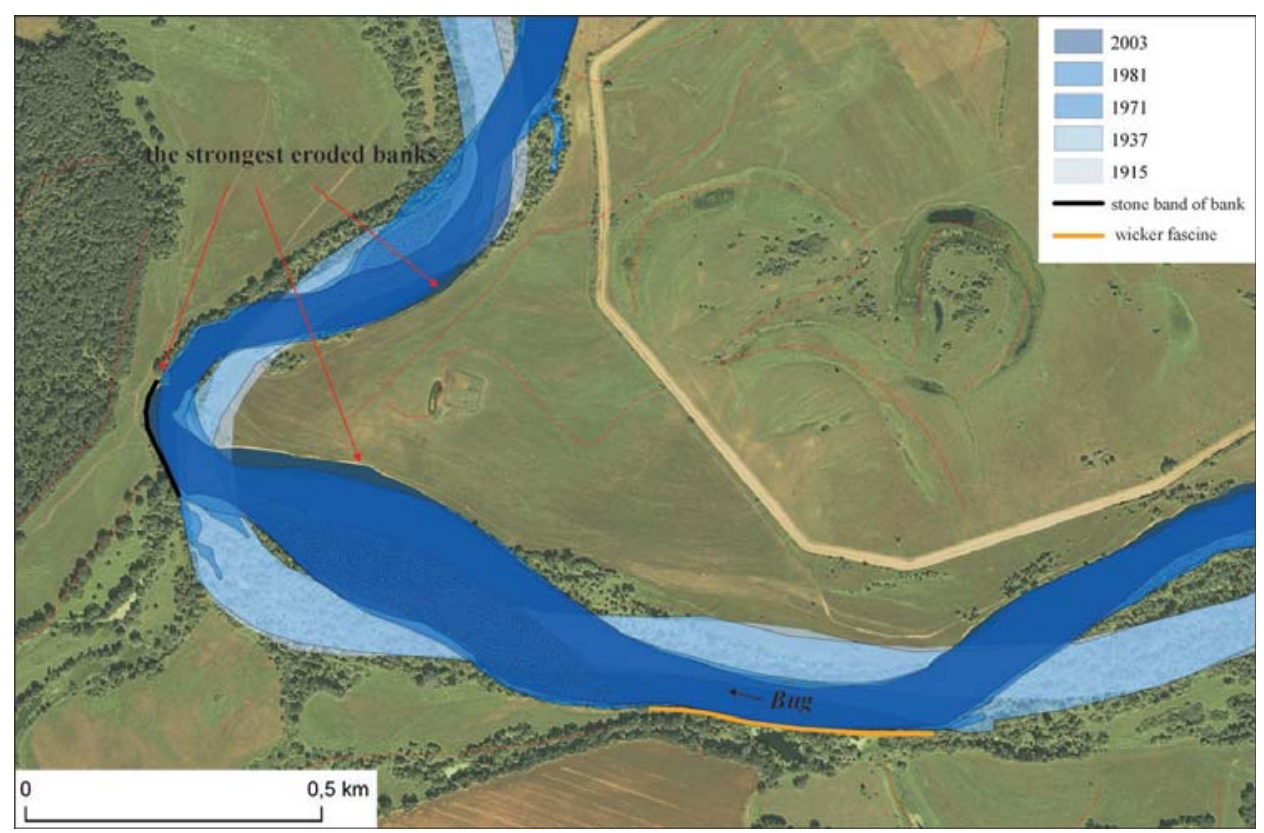

Fig. 4. The stages of bend no. 12 development 
The river bend no. 21 is the fastest downward the moving bend. Since 1911 it has changed its position by about $350 \mathrm{~m}$. The more accurate measurements based on aerial photography and orthophotomaps show that in the period 1971-2003 the channel was moved downward $40 \mathrm{~m}$. The changes of position of this bend are in accordance with the model of the river sliding along the cutting edge of the valley side (Davis 1954). The cutting edge is moraine plateau situated more than $30 \mathrm{~m}$ above the bottom of the Bug River valley. The graphic presentation of the course of event is presented below (Fig. 5).

Referring to erosional hazard, it should be underlined that meandering river, in spite of being hindered like the Bug River (as was proved above), left its own alluvial deposits. And the speed of erosion processes depends strictly on the resistance of the river bank.

\section{RIVER METAMORPHOSIS AND THE EROSION HAZARD}

The adaptation of the river channel to changeable climatic conditions causes the changes within its channel. In geological history the river evolves from one type to another. This variability of channel pattern with the passing of time is called river metamorphosis (Schumm 1969, 1971). Sometimes in the transition from one channel pattern to another the river displays characteristic features of both types of channel. This is called the transitional phase of river. If the river evolves to the braided river, it is determined as a "wild" river (e.g. Falkowski 1970).

There is river metamorphosis in the two sections of the investigated valley. In the wide section of the valley, between Zaczopki and Wygoda, during the high level of water the floodplain is partly flooded (total flooding occurs only during one hundred-year flood). In practice every year, during the spring thaw (normally appearing there) the land depression located closest to the river is flooded. In the two- or treeyear cycle the flooding water also fills the topographic low area located further from this river. Only some of the highest fragments of floodplain are above the surface of water. Then the Bug River has many features of anastomosis river (Fig. 6). Anastomosed rivers consist of two or more interconnected, co-existing channels with the interceptor (transport) or distributed character (Teisseyre 1991). The flooding water usually flows into paleochannels/oxbows, confirmed by fillers of mineral deposits. This flooding water flows also in overflow channels which connect the paleochannels. The erosion of floodplain occurs during that reorganization of channel.

The developing river bends in the narrow section of the Big River valley, between Wygoda and Gnojno, have never been unhindered meanders, either. Due to channel swinging from one valley side to another (also by avulsion), the river created more or less randomly curves of channel similar to meanders. Then meanders should be called constrained meanders or semi-meanders. In this case erosion hazard is similar to restrainted meanders, but there the probability of avulsion is 
significantly higher. The river evolves to braiding in this narrow section of the valley. Islands (bars) are recently developing within the channel (Fig. 7). They are the first, slightly visible, but certain evidence for evolution of the Bug River to braiding. According to Falkowski (1970), Babiński (1992) or Klimek (1987), human activity in the river valley and adjacency to its moraine plateau play an important role for transformation of this river to braiding. In this section of the valley the aggradation is dominating.

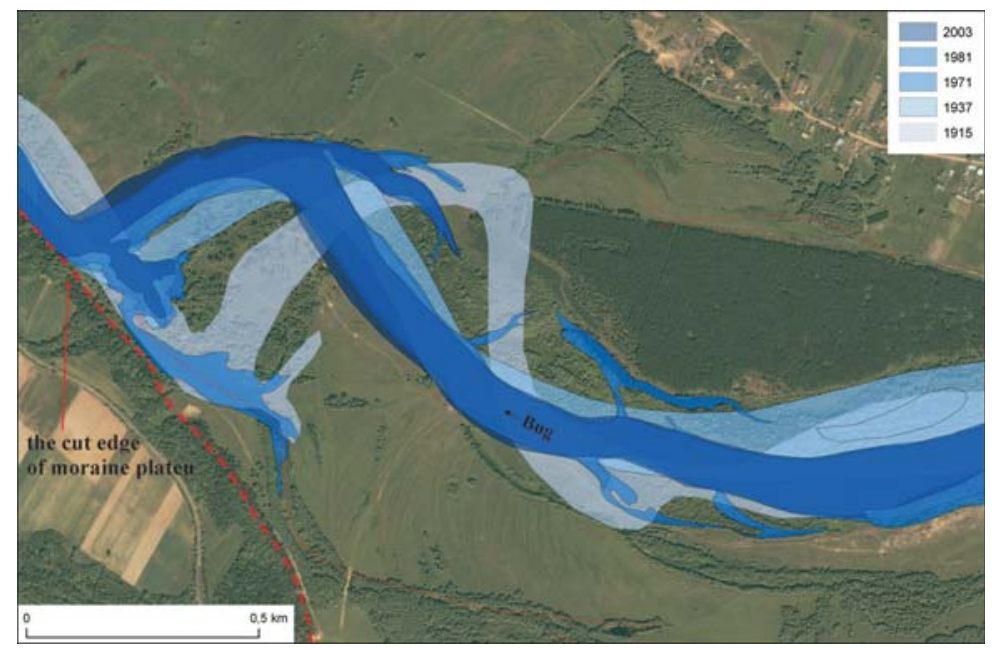

Fig. 5. The fast sliding bend no. 21 along to the cutting edge

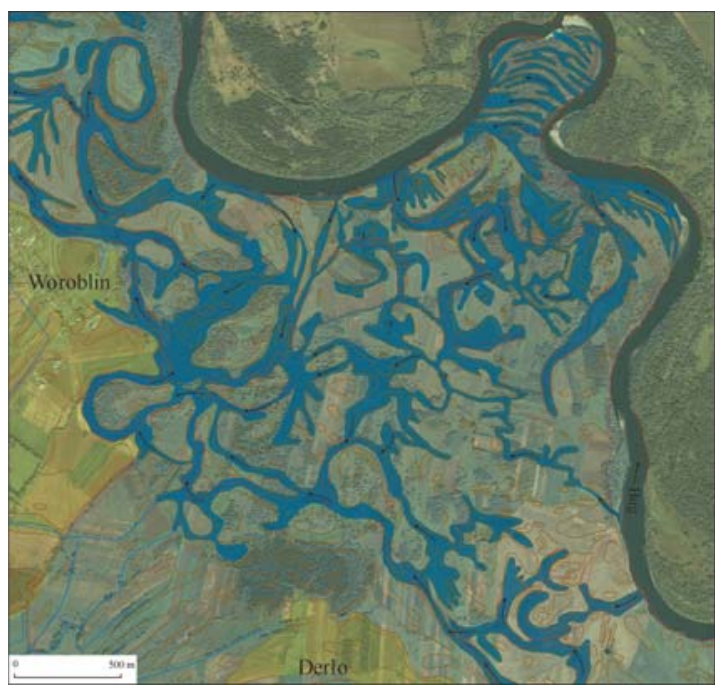

Fig. 6. The two-year floods in the left-bank Bug River valley, wide section of valley near Derło and Woroblin (based on Plan operacyjny ochrony przed powodziq..., 2003 and author's observation). Arrows mark the direction of flooding water in topographic depressions 

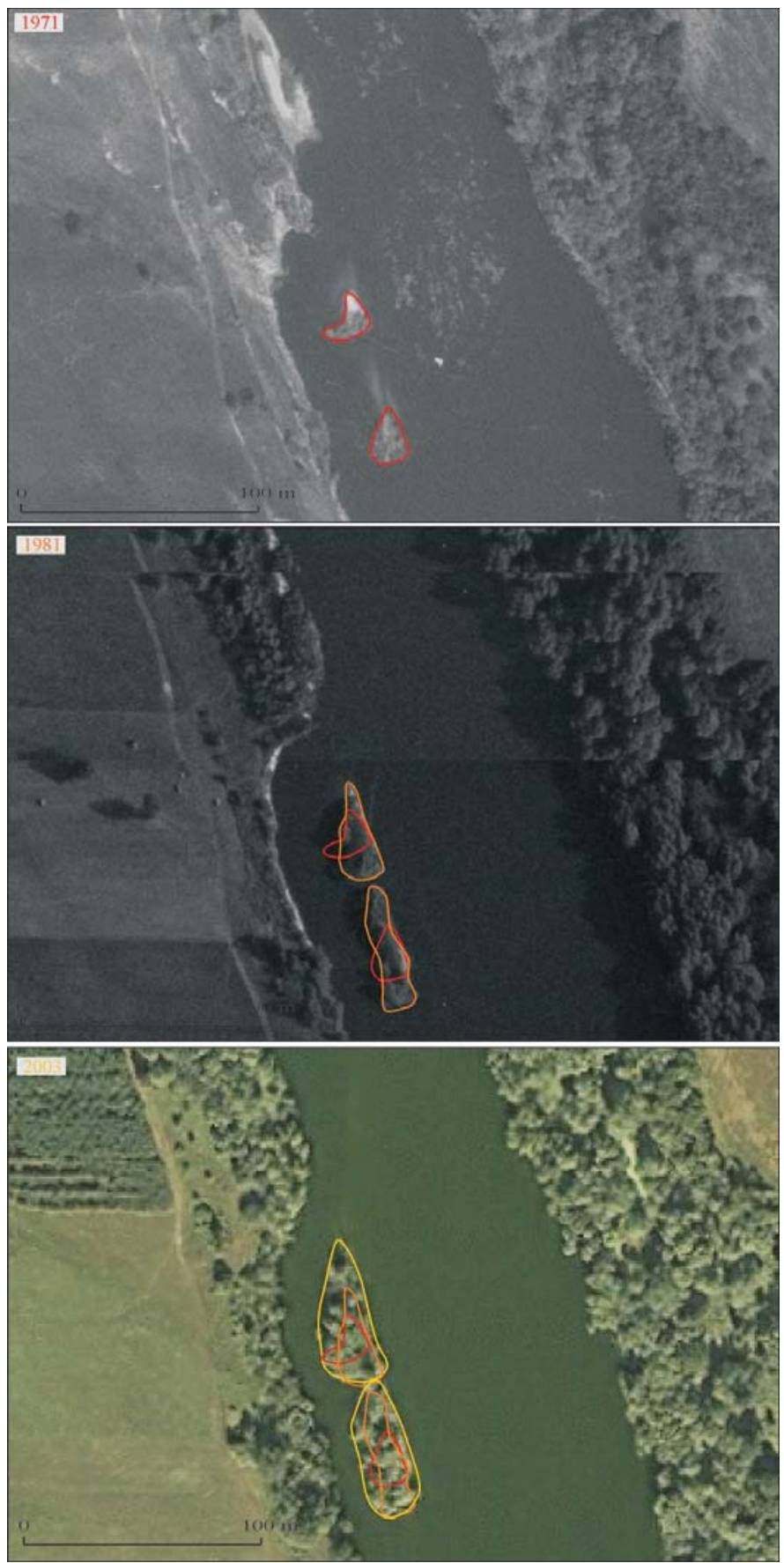

Fig. 7. The islands development near Bubel-Łukowiska in the following years: 1971, 1981, 2003 


\section{CONCLUSION AND FINAL COMMENTS}

The carried out research allows to determine the erosion hazard of particular river bends using the changes of position and its morphometric features.

The bends of the Bug River located in the section between Zaczopki and Wygoda are generally characteristic of meandering river. Only in the four cases these are unhindered meanders being usually in the initial phases of development. The straight majority of meanders are hindered by resistance of channel bank. This is connected with geology of alluvial deposits (deposits of paleochannels and older floodplain are usually more resistant) and human activity (lateral erosion limited by the constructed band or fascine and the residues after economic human activities). In this wide section of valley the lateral migration of the Bug River channel has been limited. The majority of meanders existing there are restrained. Near the Wygoda village the channel pattern is changed. The channel becomes straight, the lateral erosion is slight. The developed river bends are constrained by geology of surrounding moraine plateau in the narrow section of the valley between Buczyce Stare and Gnojno. Furthermore, the channel there is taking more and more features of braiding river, the channel is wider with a few islands. Opposite to meandering river, where one bank is strongly eroded and another is accumulated, in the braiding river two banks on the longer distance are simultaneously eroded. The research indicates smaller changes in the position of the channel with braiding tendency. In this case the longer section of channel is being moved. The conducted analysis of changes in channel position show that the cutting off meanders were twice in the analyzed section of the valley. In both cases the benefits were for Poland. The bend no. 5 is in danger by cutoff in the near future. Then Belarus will benefit. Taking into consideration human impact on the Bug lateral erosion it must be stated that man's activity has only a slight influence on such a big river.

In the light of the conducted studies it is possible to forecast the future of channel Bug River transformation (assuming without a big climatic change or human activity). In the wide section of the Bug River valley, from Zaczopki to Wygoda, the river is transporting its own deposits as a result of channel lateral migration. There is a little probability of changes in channel pattern, but significant changes of channel position/channel migration will take place depending on the resistance of river banks. The used wicker fascines against lateral erosion protect the banks in relatively short time; the fascines are being washed over and damaged (mainly beginning from the bottom of fascine). The using of stone band of the bank is much more effective, but the band must be well localized and long enough. In the narrow section of the valley, between Buczyce Stare and Gnojno, the process of transformation of the channel to braided river will continue. The amount of islands will increase; the channel will be more shallow and wider. The lateral erosion will continue to move the longer sections of the channel taking the Polish or Belarus territory. 
In the aspect of dwellings the phenomenon of flood is very dangerous, but fortunately, in the Bug River valley the houses are located mostly safely. Only in the case of one hundred-year flood the dwellers are really in danger. The lateral erosion is not dangerous for dwelling houses because not even a single house is not situated close to the channel.

\section{REFERENCES}

Babiński Z., 1992: Współczesne procesy korytowe Dolnej Wisty. Pr. Geogr. 157, WrocławWarszawa-Kraków, 169.

Davis W. M., 1954: Geographical Essays. Dover Publications INC, Dover.

Falkowski E., 1970: Historia i prognoza rozwoju układu koryta wybranych odcinków rzek nizinnych Polski. Biul. Geol., 12, 5-121.

Gloger Z., 1903: Dolinami rzek. Opis podróży wzdluż Niemna, Wisty, Bugu i Biebrzy. Printed by Ferdynand Mosicki, Warszawa.

Klimek K., 1987: Man's impact on fluvial processes in the Polish Western Carpathians. Geogr. Ann., 69A, 221-226.

Kondracki J., 2000: Geografia regionalna Polski. PWN, Warszawa, 440.

Kondratiew W. E., 1968: Gidromorfołogiczeskije processy i metody ich izuczenija. Izd. G. G. I., Leningrad.

Kostrzewski A., 2002: Powodzie - transformacja i rozwój krajobrazu, [in:] J. Kułtuniak (ed.), Rzeki - kultura, cywilizacja, historia, 10, Wyd. Nauk., Katowice, 87-98.

Leopold L. B., Wolman M. G., 1960: River Meanders. Geol. Soc. Ann. Bull., 71.

Lajczak A., 1988: Impact of various land use on the intensity of sediment runoff in the Polish Carpathians flysch catchments. Interpraevent 1988 - Graz, Tagungspubl., 3, 131-165.

Michaluk D., 2004: Góra Zamkowa w Mielniku - siedziba wielkoksiqżęcego zamku, [in:] R. Dobrowolski, S. Terpiłowski (eds.), Stan i zmiany środowiska geograficznego wybranych regionów wschodniej Polski, Wyd. UMCS, Lublin, 299-304.

Mierkiewicz M., Sasim M., 2003: Warunki formowania się odpływu - powodzie i susze, [in:] J. Dojlido, W. Kowalczewski, R. Miłaszewski, J. Ostrowski (eds.), Rzeka Bug-zasoby wodne i przyrodnicze, IMGW, Warszawa, 56-71.

Plan operacyjny ochrony przed powodziq wraz z późniejszymi uzupetnieniami, Janów Podlaski District Council, Janów Podlaski 2003.

Schumm S. A., 1969: River metamorphosis. Journal of Hydraulic Division of the American Society of Civil Engineers, 95, 255-273.

Schumm S. A., 1971: Fluvial geomorphology: Channel adjustment and river metamorphosis, [in:] H. W. Shen (ed.), River Mechanics, 1, 5.1-5.22, Fort Collins, Colorado.

Teisseyre A. K., 1991: Bank crevasing and channel anastomosis in the upper River Bóbr valley (Central Sudetes, SW Poland). Pr. Geol.-Mineral., 21, Wrocław, 111.

Trafas K., 1975: Zmiany biegu koryta Wisty na wschód od Krakowa w świetle map archiwalnych i fotointerpretacji. Zesz. Nauk. UJ, Pr. Geogr., 40, Pr. Inst. Geogr., 62, 85.

\section{STRESZCZENIE}

Badania prowadzono w dolinie środkowego Bugu pod Janowem Podlaskim, na odcinku rzeki o długości $35 \mathrm{~km}$. Jest to odcinek graniczny między Polską a Białorusią. Celem badań było rozpoznanie zagrożenia erozyjnego Bugu poprzez określenie zmian położenia 
jego koryta. W tym celu zestawiono różne materiały kartograficzne (mapy archiwalne, zdjęcia lotnicze i ortofotomapy) pochodzące z okresu od $1839 \mathrm{r}$. Wnioskowanie na temat zmian położenia koryta Bugu oraz jego cech morfometrycznych prowadzono w oparciu o rozpoznanie geologiczne osadów.

Badania wskazują na wyraźny związek pomiędzy erozją boczną Bugu a odpornością brzegów jego koryta. Na ograniczenie erozji bocznej mają wpływ zarówno czynniki naturalne (odporne osady wypełnień paleokoryt oraz teras nadzalewowych), jak i antropogeniczne (opaski brzegowe, faszyny przeciwerozyjne oraz pozostałości po dawnym gospodarowaniu człowieka). Na skalę erozji wpływa również wzór koryta rzeki. Niektóre zakola Bugu od $1911 \mathrm{r}$. przesunęły się o ponad $350 \mathrm{~m}$. Zdecydowana większość tych zakoli to meandry skrępowane lub wymuszone. Na kilku odcinkach Bug ewoluuje w kierunku rzeki roztokowej (rzeki „dzikiej”).

W świetle przeprowadzonych badań istnieje duże zagrożenie erozją boczną Bugu. Zmiany położenia koryta Bugu powodują odcinanie znacznych obszarów Polski czy Białorusi, proces ten przebiega dość równocześnie. Powodzie wiosenne są również bardzo niebezpieczne; czasami są to powodzie zatorowe. $\mathrm{Z}$ uwagi jednak na lokalizację domów mieszkalnych są one raczej nienarażone na te zagrożenia.

Słowa kluczowe: erozja boczna, metody kartograficzne, wzór koryta, dolina rzeki Bug 